\title{
Pharmacological Management of Cushing's Syndrome: An Update
}

\begin{abstract}
The treatment of choice for Cushing's syndrome remains surgical. The role for medical therapy is twofold. Firstly it is used to control hypercortisolaemia prior to surgery to optimize patient's preoperative state and secondly, it is used where surgery has failed and radiotherapy has not taken effect. The main drugs used inhibit steroidogenesis and include metyrapone, ketoconazole, and mitotane. Drugs targeting the hypothalamic-pituitary axis have been investigated but their roles in clinical practice remain limited although PPAR- $\gamma$ agonist and somatostatin analogue som-230 (pasireotide) need further investigation. The only drug acting at the periphery targeting the glucocorticoid receptor remains Mifepristone (RU486). The management of Cushing syndrome may well involve combination therapy acting at different pathways of hypercortisolaemia but monitoring of therapy will remain a challenge. (Arq Bras Endocrinol Metab 2007;51/8:1339-1348)
\end{abstract}

Keywords: Cushing's syndrome; Drug therapy; Steroidogenesis inhibitor; Hypothalamic-pituitary modulator

\section{RESUMO}

Manejo Farmacológico da Síndrome de Cushing: Uma Atualização. O tratamento de escolha para a síndrome de Cushing ainda é a cirurgia. O papel da terapia medicamentosa é duplo: ele é usado para controlar o hipercortisolismo antes da cirurgia e otimizar o estado pré-operatório do paciente e, adicionalmente, quando ocorre falha cirúrgica e a radioterapia ainda não se mostrou efetiva. Os principais medicamentos são empregados para inibir a esteroidogênese e incluem: metirapona, cetoconazol e mitotano. Medicamentos visando o eixo hipotálamo-hipofisário têm sido investigados, mas seu papel na prática clínica permanece limitado, embora o agonista PPAR- $\gamma$ e análogo de somatostatina, som-230 (pasireotídeo), requeira estudos adicionais. A única droga que age perifericamente no receptor glicocorticóide é a mifepristona (RU486). O manejo da síndrome de Cushing deve envolver uma combinação terapêutica atuando em diferentes vias da hipercortisolemia, mas o monitoramento dessa terapia ainda permanece um desafio. (Arq Bras Endocrinol Metab 2007;51/8:1339-1348)

Descritores: Síndrome de Cushing; Terapia médica; Inibidores da esteroidogênese; Moduladores hipotálamo-hipofisários atualização

\section{Cuong nguyen Dang \\ Peter TRainer}

Christie Hospital,

Manchester, UK.

Recebido em 01/10/07 Aceito em 08/10/07 
C USHING'S IS A RARE DISEASE and therefore of minimal interest to the pharmaceutical industry and hence for many years there were few developments. However in recent times there has been renewed interest in whether agents marketed for other conditions may have a role to play in the medical management of Cushing's syndrome. This review will endeavour to assess the place of the 'new' agents alongside the longer established agents.

The definitive management for Cushing's syndrome is surgical excision of the underlying cause of the hypercortisolaemia, with the exception of ACTHindependent bilateral macronodular hyperplasia where pharmacological treatment directed against the aberrant receptor can be effective (1). However, in many patients with Cushing's syndrome there is a role for medical therapy in certain specific circumstances. It is common practice to prepare patients for surgery by lowering circulating cortisol levels to reverse the metabolic consequence of cortisol excess and by implication reduce the complications of surgery. This clearly depends on the interval to surgery and disease severity. As any clinician dealing with Cushing's syndrome is aware establishing the precise aetiology is a challenge and it is not always possible to make a definitive diagnosis at first investigation, and in such cases medical therapy can be used as a stop gap to control signs and symptoms and thereby allow time for re-investigation. In patients not cured by surgery or in patients with metastatic disease medical therapy can be used to control manifestations of the disease. Pituitary radiotherapy is extremely effective at controlling hypercortisolaemia but can take several years to have its full effect and medical therapy is often required in the interim (see figure $\mathrm{l}$ ).

Medical therapy can be separated into agents that inhibit adrenal steroidgenesis and those that modulate pituitary ACTH release. Currently in clinical practice, the most effective, reliable and widely use agents are those that inhibit steroidgenesis.

A major challenge of medical therapy is the monitoring of its effectiveness. Urinary free cortisol (UFC) measurement is widely used but has several major limitations and is intrinsically a poor solution to the problem of disease monitoring. Only a small proportion of cortisol is excreted unaltered in urine and UFC immunoassays to varying extent detect biologically inactive cortisol metabolites, which may be raised in patients treated with agents such as metyrapone. UFC has the additional disadvantages of relying on complete collection and of being unable to detect over-treatment induced hypoadrenalism.
Although more labour intensive, measurement of serum cortisol is a more appropriate means of assessing disease activity. The best validated technique is calculation of a mean serum cortisol from multiple measurements taken during a single day. Studies comparing isotopically calculated cortisol production rates
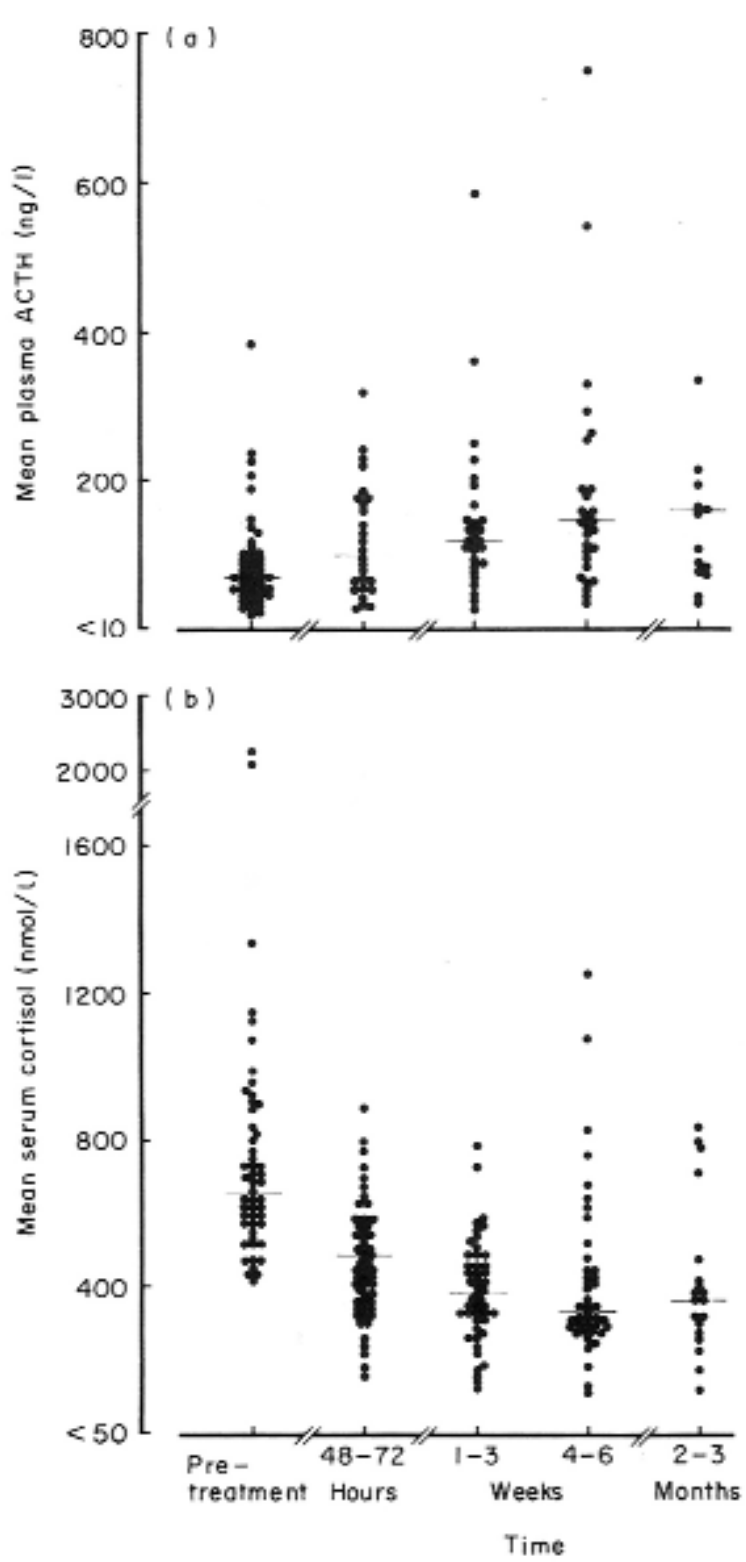

Figura 1. Mean plasma ACTH levels (a) and serum cortisol levels (b) during short-term metyrapone therapy in 53 patients with Cushing's syndrome. The bars represent the median values. ACTH ng/L $\times 0.225=\mathrm{pmol} / \mathrm{l}$. [Courtesy of Verhelst JA, Trainer PJ, Howlett TA, et al. Short- and long-term responses to metyrapone in the medical management of 91 patients with Cushing's syndrome. Clin Endocrinology (Oxf) 1991;35:169-78] 
to serum levels indicate that a mean serum cortisol in the range $150-300 \mathrm{nmol} / \mathrm{l}$ equates to a normal cortisol production rate, and this should be the target of medical therapy (2).

The cyclical nature of Cushing's syndrome in some patients means that even after disease control has been achieved regular treatment monitoring is required.

\section{STEROIDOGENESIS INHIBITION}

These agents are the most consistently effective means of controlling cortisol secretion.

\section{Metyrapone}

In the era before it was possible to measure plasma ACTH, the metyrapone test was used to investigate suspected Cushing's syndrome and hypoadrenalism but its use now is exclusively therapeutic $(3,4)$. It acts primarily on the final step in cortisol synthesis namely the conversion of 11-deoxycortisol to cortisol and therefore results in a dramatic increase in circulating 11-deoxycortisol levels, which can cross-react in serum and urine cortisol immunoassays. This cross-reactivity may result in spuriously elevated cortisol levels and a failure to appreciate that a patient is over-treated and hypoadrenal.

Metyrapone is the most potent, short-acting inhibitor of cortisol synthesis with a rapid onset of action. Serum cortisol levels fall within four hours of an initial dose and care is required to avoid over-treatment. The routine starting dose is $250 \mathrm{mg}$ three times per day with reassessment of cortisol levels 72 hours later and dose titration as appropriate until a mean cortisol level of between 150 and $300 \mathrm{nmol} / \mathrm{l}$ is achieved. In patients with severe hypercortisolaemia up to $8 \mathrm{gm}$ per day in 3-4 divided doses may be necessary. Most patients tolerate the drug without difficulty as long as hypoadrenalism is avoided. Nausea, anorexia and abdominal pain can occur but usually this is a sign of over-treatment. The major limitation of metyrapone is in women as the accumulation of cortisol precursors results in elevated androgens, which frequently is manifest as hirsutism and acne. Although mineralocorticoid precursors levels are elevated, hypokalaemia, hypertension and oedema are not problems, presumably because of the benefits of lower circulating cortisol levels $(5,6)$. In patients with pituitary-dependent Cushing's disease, ACTH levels rise but there is no evidence that this results in tachyphylaxis $(5,7)$.

\section{Ketoconazole}

Ketoconazole is an imidazole derivative developed as an oral antifungal agent that inhibits cholesterol, sex steroid and cortisol synthesis by acting on the $11 \beta$-hydroxylase and C17-20 lyase enzymes (8-11). It is the most frequently used agent in the treatment of Cushing's syndrome with the starting dose being 200 $\mathrm{mg}$ twice daily increasing as necessary to $1200 \mathrm{mg}$ /day in four divided doses $(12,13)$. In contrast to metyrapone it can take several weeks to see the full benefit of a dose adjustment and there is less risk of over-treatment and hypoadrenalism. With time it is effective at controlling the symptoms of Cushing's syndrome and in women its antiandrogenic properties are a virtue but in men, gynaecomastia and reduced libido have been reported. The most common side effects are gastrointestinal upset and skin rashes but liver enzyme dysfunction can occur in up to $10 \%$ of cases, which rarely has proceeded to acute liver failure and fatality (14-17). Ketoconazole has the added benefit of reducing the total cholesterol and LDL cholesterol (18).

Metyrapone and ketoconazole can be very successfully co-administered as the former controls cortisol secretion while waiting for the slower onset of action of the latter agent, which in turn lowers androgens and thus negates one of the major limitations of the former.

\section{Mitotane}

Mitotane reduces cortisol production by blocking cholesterol side-chain cleavage and $11 \beta$-hydroxylase (19-21). It was introduced in 1960 for the treatment of adrenal carcinoma and subsequently used for the treatment of benign causes of Cushing's syndrome. The onset of mitotane action is slow with sustained action maintained after discontinuation in up to a third of patients (22). When used to control serum cortisol levels in benign disease, mitotane is initiated at a dose of $0.5-1 \mathrm{gm}$ per day which is increased gradually by $0.5-1$ gm every few weeks to minimise side effects. Adverse effects such as nausea, anorexia and diarrhoea are common with doses of $2 \mathrm{gm}$ per day and almost universal at doses greater than $4 \mathrm{gm}$ per day (23). Adrenal insufficiency and neurological side effects including abnormal gait, dizziness, vertigo, confusion and problem of language expression are often seen at higher dose (22). Abnormal liver enzymes, hypercholesterolaemia, skin rash, hyporuricaemia, gynaecomastia in male and prolonged bleeding time are also well recognized $(24,25)$. Changes in hormone binding globulins may result in total hor- 
mone measurement being unreliable during treatment and thus caution is required when interpreting serum cortisol levels $(26,27)$. Mitotane increases the metabolic clearance of exogenously administered steroid and the replacement dose of steroid is increased by about a third (28). In order to minimise side effects mitotane dose should be gradually titrated up, taken with meals or at bedtime with food. Changing the schedule to once daily or alternate day may help with gastrointestinal problems. If side effects are severe mitotane can be stopped for a week and restarted at a lower dose. Mitotane may induce spontaneous abortion and is a teratogen. Its effect may persist for a number of months after discontinuation and so a female patient should avoid pregnancy for up to five years after stopping the drug (29).

\section{Aminoglutethimide}

Aminoglutethimide, which was introduced in 1959 as an anticonvulsant, has also been used in the treatment of breast cancer and was noticed to induce adrenal insufficiency. It inhibits the side-chain cleavage of cholesterol to pregnenolone and therefore inhibits cortisol, oestrogen and aldosterone production and additionally inhibits $11 \beta$-hydroxylase, 18 -hydroxylase and aromatase activity $(30,31)$. Initially aminoglutethimide decreases cortisol production in Cushing's syndrome but appears to be less effective in treating Cushing's disease (32). The suggested mechanism may be an increase in ACTH overcoming the enzymatic blockade or it may be induction of hepatic enzyme accelerating aminoglutethimide metabolism $(33,34)$. Adverse effects such as lethargy, dizziness, ataxia and rashes are common on initiation and limit its use although they do resolve with time $(32,35)$. There are better agents for controlling hypercortisolaemia and aminoglutethimide does not have a place in the modern treatment of Cushing's syndrome (36).

\section{Trilostane}

Trilostane is a competitive inhibitor of $3 \beta$-hydroxysteroid dehydrogenase, which is an essential enzyme in the synthesis of cortisol, aldosterone and androstenedione. It is an effective inhibitor of steroid synthesis in vitro but in man the results have been disappointing (37). However, it is used in veterinary practice as it is very effective in controlling pituitary-dependent Cushing's in dogs (38). The maximum daily dose is 1,440 $\mathrm{mg}$ and patients may experience side effects such as abdominal discomfort, diarrhoea and paraesthesia. Trilostane has largely fallen out of clinical use but the very fact that it is so effective in dogs may mean it justifies reconsideration in man.

\section{Etomidate}

Etomidate is a parenteral anaesthetic agent which when first introduced was associated with excessive mortality in patients in intensive care which was ultimately explained by the recognition it lowered circulating cortisol levels by inhibiting 11 $\beta$-hydroxylase, 17-hydroxylase, c17-20 lyase as well as cholesterol side chain at cleavage (39-41). A number of case reports have shown etomidate at $2.5 \mathrm{mg} /$ hour to be effective at correcting hypercortisolaemia in seriously ill patients with ectopic ACTH production (42-44). Etomidate's use is limited by the need to be given intravenously but it has a place in acutely sick patients unable to be treated orally where rapid correction of hypercortisolaemia may be life saving.

\section{HYPOTHALAMIC-PITUITARY NEUROMODULATORY AGENTS}

Pituitary ACTH secretion is regulated by a number of neurotransmitters including catecholamines, serotonin, acetylcholine, GABA and peptides. In Cush-

Table 1. Agents inhibiting steroidogenesis in clinical use.

\begin{tabular}{|c|c|c|}
\hline Agent & Dose & Properties \\
\hline \multirow[t]{2}{*}{ Metyrapone } & $750-8000$ & Hypoadrenalism \\
\hline & mg daily & Side effects: nausea, abdominal pain, hirsutism, acne \\
\hline \multirow[t]{2}{*}{ Ketoconazole } & $400-1200$ & Slow onset of action \\
\hline & mg daily & $\begin{array}{l}\text { Side effects: gastro-intestinal upset, rashes, abnormal } \\
\text { LFT, gynaecomastia \& reduced libido in men }\end{array}$ \\
\hline \multirow[t]{2}{*}{ Mitotane } & $500-8000$ & Gradual dose titration, taken with meal \\
\hline & mg daily & $\begin{array}{l}\text { Side effects: gastro-intestinal upset, neurological } \\
\text { disturbances, abnormal LFT, hypercholesterolaemia } \\
\text { Avoid preanancy up to five years after stopping the drua }\end{array}$ \\
\hline
\end{tabular}


ing's disease the pituitary tumour still remains partially responsive to hypothalamic stimuli, illustrated by responsiveness to exogenous $\mathrm{CRH}$ and dexamethasone. Reports exist advocating the virtues of various agents but, to-date, none have gained widespread acceptance. However recent data have renewed interest in the possibility of treating Cushing's disease with centrally acting drugs that modulate through dopamine, somatostatin and PPAR receptors function.

\section{Dopamine agonists}

Bromocriptine is a dopamine agonist which has been widely used in the treatment of hyperprolactinaemia and acromegaly. It is unclear if the action in lowering ACTH secretion by bromocriptine is via $\mathrm{CRH}$ or directly on the pituitary (45-47). A single dose of bromocriptine will cause a fall in ACTH in half of the patients with Cushing's disease but unfortunately this effect is not maintained in the long term $(47,48)$. There are reports that suggest with high dose bromocriptine $(40 \mathrm{mg} /$ day) there may be clinical improvement in up to $50 \%$ of patients but others have found response rate of only $1-2 \%$ in the long term $(49,50)$. Potential side effects of bromocriptine include nasal congestion, nausea, postural hypotension, headaches and hallucination.

The use of cabergoline in the management of Cushing's disease remains anecdotal. In mixed pituitary tumour secreting prolactin and ACTH with florid clinical signs of Cushing's disease treatment with cabergoline resulted not only in the normalisation of prolactin but also clinical and biochemical resolution of the features of Cushing's (51). It has also been use to control Cushing's disease in failed pituitary surgery $(52,53)$. Recently there has been renewed interest in cabergoline with the publication by Pivonello et al. of a case of lung carcinoid with Cushing's syndrome treated with a combination of lanreotide and cabergoline successfully normalising plasma ACTH and UFC levels (54). In a study of six patients with ACTHsecreting neuroendocrine tumours, dopamine D2 receptors were expressed in five patients on immunohistochemistry and treatment with cabergoline 3.5 $\mathrm{mg}$ /week for six months normalised UFC in two patients although one patient later did have treatment escape (55). Case reports of cabergoline use in Nelson's syndrome have been more encouraging. Casulari et al. reported a case of Nelson's syndrome with failed treatment on cyproheptadine $(12 \mathrm{mg} /$ day $)$ and bromocriptine $(7.5 \mathrm{mg} /$ day $)$ but cabergoline $(0.5 \mathrm{mg}$ twice weekly) normalised the ACTH plasma levels and induced complete resolution of the pituitary adenoma on MRI (56). There has also been a case report of cabergoline $(1.5 \mathrm{mg} /$ week) treatment of Nelson's syndrome for six years with normalisation of ACTH levels and stable residual pituitary tumour (57).

The role of dopamine agonists in the management of Cushing's disease remains limited to the occasional patient and long-term evidence of efficacy is very poor but interest in their use remains unabated. The available data are case based anecdote, there is a need for a controlled study before treatment can be recommended.

\section{PPAR- $\gamma$ receptor agonists}

In 2002, the nuclear hormone receptor, peroxisome proliferator-activated receptor- $\gamma$ (PPAR- $\gamma$ ) was identified in ACTH-secreting pituitary tumour (58). In an in vivo experiment, innoculating mice with corticotroph AtT20 tumour cells, treating with extremely high dose of rosiglitazone $(150 \mathrm{mg} / \mathrm{kg} /$ day $)$ prevented the development of tumours. In mice with already established corticotroph tumours, rosiglitazone treatment decreased tumour volume in $75 \%$ of cases and prevented signs of hypercortisolaemia in all cases, with $75 \%$ reduction in ACTH level and 96\% reduction in cortisol levels (58). These observations caused great interest but are yet to impact on clinical practice.

In a study of two patients with pituitary-dependent Cushing's syndrome treated with rosiglitazone 8 $\mathrm{mg}$ daily for 33 and 20 days (the second patient was also taking metyrapone $1 \mathrm{gm} /$ day), 24 hours UFC fell in both patients although only in the patient co-treated with metyrapone did it reach statistical significance (59). In a second study of ten patients, four prior to surgery, four following relapse after surgery and two immediately after failed surgery treated with $4-16 \mathrm{mg}$ of rosiglitazone for $1-8$ months (median 3 months), there was no consistent reduction in urinary free cortisol, plasma ACTH or serum cortisol levels (60). Side effects reported included oedema, weight increase, somnolence and increased hirsutism. In one of the larger studies, fourteen patients with active Cushing's disease (seven untreated and seven post unsuccessful transsphenoidal pituitary surgery) were treated with $8-16 \mathrm{mg}$ of rosiglitazone for $1-7$ months (61). In six patients, plasma ACTH, serum cortisol and 24 hours UFC were lowered but only UFC reached significance. Two of the six patients also noted clinical improvement on follow up at seven months. No clinical side effects were noted but one patient developed hypercholesterolaemia. In a study of seven patients with Nelson's syndrome who took $8 \mathrm{mg}$ of rosiglitazone for 12 weeks, no significant fall in ACTH was seen (62). Sim- 
ilarly in another study of six patients with Nelson's syndrome given rosiglitazone $12 \mathrm{mg}$ per day for 14 weeks, there was no fall in ACTH levels (63).

Although most studies used rosiglitazone in treating Cushing's disease, pioglitazone has also been tried. In a study of five patients with Cushing's disease treated with pioglitazone $45 \mathrm{mg}$ for 30 days, no alteration in 24 hours UFC, or ACTH and cortisol responses to CRH administration was seen (64).

Currently the success of PPAR agonists in treating Cushing's disease remains disappointing, failing to reproduce the success seen in the in vitro and mouse model. However with the small number of patients and short duration of treatment, further studies are still needed. The discrepancy between the in vitro and human experience may reflect the differences in the order of magnitude in the dose of rosiglitazone.

\section{Somatostatin analogues}

Octreotide, an analogue of somatostatin, has been used extensively to treat neuroendocrine tumours and acromegaly. In the 1990s five subtypes of somatostatin receptors were identified with expression of somatostatin receptor subtypes in mammalian corticotrophs being variable $(65)$.

In one study all five subtype somatostatin receptors were co-localised in rat pituitary cells expressing ACTH (66). Yet in another study only $38 \%$ of corticotrophs expressed somatostatin receptor subtype 5 (sst5) and 3\% expresses somatostatin receptor subtype 2 (sst2) (67). While in contrast Smith et al. found a predominance of sst 2 rather than sst5 (68). It is generally accepted that sst 2 and sst 5 are involved in the regulation of growth hormone, prolactin and TSH (69).

In vitro studies suggested that normal corticotroph only responds to somatostatin with inhibition of ACTH release if the cells have been cultured in glucocorticoid free medium (70-74). In agreement with this is the finding that ACTH secretion in normal individuals is not affected by infusion of somatostatin or octreotide but is affected in patients with Addison's disease $(75,76)$.

Initial reports did show that somatostatin infusion decreases plasma ACTH level by between $40 \%$ to $70 \%$ in patients with Nelson's syndrome (77). However, subsequent studies in Nelson's syndrome have been less impressive and most patients with Cushing's disease have failed to respond (78-82). The chronic treatment of rat pituitary tumour cells and mouse corticotroph cells with glucocorticoid results in decreased binding of somatostatin (83). In cultured human corticotroph, adenoma cells pre-treated with hydrocortisone resulted in abolition of octreotide-induced inhibition of basal and $\mathrm{CRH}$ induced ACTH release (82). The lack of clinical efficacy of octreotide may be due to the down regulation of somatostatin receptors by glucocorticoids. In fact in the mouse, sst2 gene promoter sequence is the only somatostatin receptor shown to be directly transcriptionally regulated by glucocorticoids $(84,85)$. There has been speculation that octreotide may have a role in treating ectopic ACTH producing tumours or in Cushing's disease in combination with ketoconazole but the available evidence is unconvincing that it has any role in Cushing's disease $(86,87)$.

There is renewed interest in somatostatin analogues in Cushing's disease because of encouraging data emerging from early studies with SOM-230 (pasireotide, Novartis Pharmaceuticals UK Ltd). It is a new somatostatin analogue with affinity to all the somatostatin receptor subtypes but with 40 fold higher affinity for sst5 than octreotide (88-90).

Compared to octreotide, SOM-230 is more potent at suppressing ACTH release and at inhibiting $\mathrm{CRH}$-induced ACTH release in corticotroph tumour cells (91-93). Dexamethasone (10 nM) pre-treatment of mouse corticotroph cells fails to suppress SOM-230 inhibition of $\mathrm{CRH}$-induced ACTH release whereas the suppressive effect of octreotide is blocked (92).

The preliminary results of an open label, single arm phase 2 study of fourteen patients with persistent or recurrent Cushing's disease treated with pasireotide 600 $\mu \mathrm{g}$ subcutaneously twice daily for fifteen days, were reported as an abstract at ENDO 2006 (94). Pasireotide normalised UFC in 3 patients $(21 \%)$ and in a further 7 patients there was at least $40 \%$ reduction in UFC compared to baseline. There was significant improvement in symptoms including weight loss, facial rubor, abdominal obesity, fatigue and proximal weakness in over $40 \%$ of patients. The drug was well tolerated but common side effects were mild to moderated gastrointestinal upset, injection site reaction and a transient increase in fasting blood glucose with one pre-existing diabetes mellitus patient stopping treatment early. Although the results of this preliminary study are encouraging the final results are awaited and further studies will be required to confirm these results.

\section{Cyproheptadine}

Cyproheptadine is a non-selective histamine and serotonin antagonist. In a small series, at a dose of $24 \mathrm{mg} /$ day, it was effective at reducing ACTH in three patients with Cushing's disease (95). There is disagreement on whether cyproheptadine acts either directly on the pituitary or through the inhibition of CRH (96-99). It is rarely effective and has no place in current practice. Its main side effect is sedation. 


\section{Ritanserin}

Ritanserin is a specific $5-\mathrm{HT}_{2}$ antagonist which has been used in a few patients but its effects do not appear to be sustained in most patients $(100,101)$.

\section{Sodium valproate}

Sodium valproate is mainly used as an anti-epileptic agent. Evidence for its effectiveness in treating Cushing's disease remains conflicting. There are reports suggesting it is successful at suppressing ACTH at a daily dose of $600 \mathrm{mg}$, but more recent data have failed to demonstrate benefit either as primary therapy or after failed pituitary surgery $(102,103)$. However, it may have a role as add on therapy to metyrapone at a daily dose of $1-2 \mathrm{~g}(104,105)$.

\section{Retinoic acid}

Since the 1980's retinoic acid derivatives are widely used by dermatologists in the treatment of acne and psoriasis as well as in certain malignancy such as acute promyelocytic leukaemia $(106,107)$. Retinoic acid is a ligand for Nur77/Nurrl receptor which is involved in the physiological stimulation of ACTH by $\mathrm{CRH}$ (108). Retinoic acid inhibits cell proliferation and induces cell death in ACTH secreting tumours but not in normal pituitary cells. In the adrenal cortex it inhibits corticosterone secretion and cell proliferation, while in a mouse model, it blocks tumour growth and reduces circulating ACTH and cortisol. The dose was $10 \mathrm{mg} / \mathrm{kg}$ which is within the dose range in human cancer therapy (108). Studies in rodents and dogs models of Cushing's disease have been successful but there is now a need for studies in human $(108,109)$.

\section{Agents blocking cortisol action}

Mifepristone (RU486) is a potent antagonist of the glucocorticoid and progesterone receptors (110). In man mifepristone blocks glucocorticoid action resulting in negative feedback at the hypothalamic-pituitary level leading to a rise in $\mathrm{ACTH}$, arginine-vasopressin and therefore cortisol (111). Mifepristone, at doses of up to $20 \mathrm{mg} / \mathrm{kg}$, has been successfully used to treat a small number of patients with ectopic ACTH syndrome and there is every reason to believe that it could be successfully used in all patients if it were not for the problem of monitoring therapy (112). As a receptor antagonist it does not lower circulating cortisol levels, which in fact rise, and therefore it is very difficult to dose titrate and judge effectiveness. The GH receptor antagonist pegvisomant has gained widespread acceptance as a treatment for acromegaly because its effectiveness can be judged by monitoring IGF-1. Unfortunately, the HPA axis lack a marker analogous to IGF-I. Even with short term use, a number of patients did develop symptoms of hypoadrenalism, which is problematic as there is no effective method of monitoring over treatment (113). There has also been report of a case of mifepristone causing severe hypokalaemia that is attributed to excess cortisol activation of mineralcorticoid receptor which responded to spironolactone therapy (114). With caution, mifepristone may have a role in the treatment of Cushing's syndrome and could be first line treatment if a biochemical measure of disease were identified (115).

\section{CONCLUSIONS}

A number of drugs have been used in the management of Cushing's syndrome. Regardless of the aetiology, steroid biosynthesis remains the most effective and widely used agent. The preferred treatments are metyrapone or ketoconazole as monotherapy, or in combination. Careful monitoring of therapy is important as all agents have the potential of causing hypoadrenalism.

Currently drugs acting on the hypothalamicpituitary pathways have been less successful in clinical practice and their role is likely to be limited to add on therapy on an individual basis. However, with the identification of new receptors and development of agent blocking these receptors, there remains the hope that they may still prove to be useful in the future.

Table 2. Potential agents for treating Cushing's syndrome.

\begin{tabular}{|c|c|c|}
\hline Receptors & Agents & Properties \\
\hline Dopamine & $\begin{array}{l}\text { Cabergoline } \\
\text { Bromocriptine }\end{array}$ & $\begin{array}{l}\text { Poor long term results but renewed interest } \\
\text { especially in treating Nelson's syndrome }\end{array}$ \\
\hline PPAR- $\gamma$ & $\begin{array}{l}\text { Rosiglitazone } \\
\text { Pioglitazone }\end{array}$ & In vitro success not reproduced in clinical practice \\
\hline Somatostatin & $\begin{array}{l}\text { SOM-230 } \\
\text { (pasireotide) }\end{array}$ & Phase 2 study show promising results \\
\hline Nu77/Nurr1 & Retinoic acid & Evaluated in mouse model \\
\hline Glucocorticoid & Mifepristone & $\begin{array}{l}\text { Successfully utilised in a small number of patients } \\
\text { Inability to monitor treatment limits usefulness }\end{array}$ \\
\hline
\end{tabular}




\section{REFERENCES}

1. Christopoulos S, Bourdeau I, Lacroix A. Aberrant expression of hormone receptors in adrenal Cushing's syndrome. Pituitary 2004; 7:225-35.

2. Trainer PJ, Eastment C, Grossman AB, Wheeler MJ, Perry L, Besser GM. The relationship between cortisol production rate and serial serum cortisol estimation in patients on medical therapy for Cushing's syndrome. Clin Endocrinol (Oxf) 1993;39:441-3.

3. Newell-Price J, Grossman AB. The differential diagnosis of Cushing's syndrome. Ann Endocrinol (Paris) 2001;62:173-9.

4. Liddle GW, Estepe HL, Kendall JWJ, Williams WCJ, Townes A. Clinical application of a new test of pituitary reserve. $\mathbf{J}$ Clin Endocrinol Metab 1959;19:875-94.

5. Verhelst JA, Trainer PJ, Howlett TA, Perry L, Rees LH, Grossman $A B$, et al. Short and long-term responses to metyrapone in the medical management of 91 patients with Cushing's syndrome. Clin Endocrinol (Oxf) 1991;35:169-78.

6. Connell JM, Cordiner J, Davies DL, Fraser R, Frier BM, McPherson SG. Pregnancy complicated by Cushing's syndrome: potential hazard of metyrapone therapy. Case report. Br J Obstet Gynaecol 1985;92:1192-5.

7. Orth DN. Metyrapone is useful only as adjunctive therapy in Cushing's disease. Ann Intern Med 1978;89:128-30.

8. Engelhardt D, Dorr G, Jaspers C, Knorr D. Ketoconazole blocks cortisol secretion in man by inhibition of adrenal 11 beta-hydroxylase. Klin Wochenschr 1985;63:607-12.

9. Oelkers W, Bahr V, Hensen J, Pickartz H. Primary adrenocortical micronodular adenomatosis causing Cushing's syndrome. Effects of ketoconazole on steroid production and in vitro performance of adrenal cells. Acta Endocrinol (Copenh) 1986;113:370-7.

10. Sonino N. The endocrine effects of ketoconazole. J Endocrinol Invest 1986;9:341-7.

11. Weber MM, Luppa $P$, Engelhardt D. Inhibition of human adrenal androgen secretion by ketoconazole. Klin Wochenschr 1989;67:707-12.

12. Angeli A, Frairia R. Ketoconazole therapy in Cushing's disease. Lancet 1985;1:821.

13. Sonino N, Boscaro M, Paoletta A, Mantero F, Ziliotto D. Ketoconazole treatment in Cushing's syndrome: experience in 34 patients. Clin Endocrinol (Oxf) 1991;35:347-52.

14. Zollner E, Delport S, Bonnici F. Fatal liver failure due to ketoconazole treatment of a girl with Cushing's syndrome. J Pediatr Endocrinol Metab 2001;14:335-8.

15. Lewis JH, Zimmerman HJ, Benson GD, Ishak KG. Hepatic injury associated with ketoconazole therapy. Analysis of 33 cases. Gastroenterology 1984:86:503-13.

16. Stricker BH, Blok AP, Bronkhorst FB, Van Parys GE, Desmet VJ. Ketoconazole-associated hepatic injury. A clinicopathological study of 55 cases. J Hepatol 1986;3:399-406.

17. Knight TE, Shikuma CY, Knight J. Ketoconazole-induced fulminant hepatitis necessitating liver transplantation. J Am Acad Dermatol 1991;25:398-400.

18. Miettinen TA. Cholesterol metabolism during ketoconazole treatment in man. J Lipid Res 1988;29:43-51.

19. Hart MM, Straw JA. Effect of 1-(0-chlorophenyl)-1-(pchlorophenyl)-2,2-dichloroethane on adrenocorticotropic hormone-induced steroidogenesis in various preparations in vitro of dog adrenal cortex. Biochem Pharmacol 1971; 20:1679-88.

20. Young RB, Bryson MJ, Sweat ML, Street JC. Complexing of DDT and o,p'DDD with adrenal cytochrome P-450 hydroxylating systems. J Steroid Biochem 1973;4:585-91.

21. Caticha O, Odell WD, Wilson DE, Dowdell LA, Noth RH, Swislocki $A L$, et al. Estradiol stimulates cortisol production by adrenal cells in estrogen-dependent primary adrenocortical nodular dysplasia. J Clin Endocrinol Metab 1993;77:494-7.

22. Luton JP, Cerdas S, Billaud L, Thomas G, Guilhaume B, Bertagna $X$, et al. Clinical features of adrenocortical carcinoma, prognostic factors, and the effect of mitotane therapy. $\mathbf{N}$ Engl J Med 1990;322:1195-201.
23. Hutter AM Jr, Kayhoe DE. Adrenal cortical carcinoma. Results of treatment with o,p'DDD in 138 patients. Am J Med 1966; 41:581-92.

24. Maher VM, Trainer PJ, Scoppola A, Anderson JV, Thompson GR, Besser GM. Possible mechanism and treatment of o,p'DDDinduced hypercholesterolaemia. Q J Med 1992; 84:671-9.

25. Haak HR, Caekebeke-Peerlinck KM, van Seters AP, Briet E. Prolonged bleeding time due to mitotane therapy. Eur J Cancer 1991;27:638-41.

26. Bledsoe T, Island DP, Ney RL, Liddle GW. An effect of o, p'DDD on the extra-adrenal metabolism of cortisol in man. $\mathbf{J}$ Clin Endocrinol Metab 1964;24:1303-11.

27. van Seters AP, Moolenaar AJ. Mitotane increases the blood levels of hormone-binding proteins. Acta Endocrinol (Copenh) 1991;124:526-33.

28. Hague RV, May W, Cullen DR. Hepatic microsomal enzyme induction and adrenal crisis due to o,p'DDD therapy for metastatic adrenocortical carcinoma. Clin Endocrinol (Oxf) 1989;31:51-7.

29. Leiba S, Weinstein R, Shindel B, Lapidot M, Stern E, Levavi H, et al. The protracted effect of o,p'-DDD in Cushing's disease and its impact on adrenal morphogenesis of young human embryo. Ann Endocrinol (Paris) 1989;50:49-53.

30. Dexter RN, Fishman LM, Ney RL, Liddle GW. Inhibition of adrenal corticosteroid synthesis by aminoglutethimide: studies of the mechanism of action. J Clin Endocrinol Metab 1967;27:473-80.

31. Shaw MA, Nicholls PJ, Smith HJ. Aminoglutethimide and ketoconazole: historical perspectives and future prospects. J Steroid Biochem 1988;31:137-46.

32. Misbin RI, Canary J, Willard D. Aminoglutethimide in the treatment of Cushing's syndrome. J Clin Pharmacol 1976; 16:645-51.

33. Zachmann M, Gitzelmann RP, Zagalak M, Prader A. Effect of aminoglutethimide on urinary cortisol and cortisol metabolites in adolescents with Cushing's syndrome. Clin Endocrinol (Oxf) 1977;7:63-71.

34. Sonino N, Boscaro M. Medical therapy for Cushing's disease. Endocrinol Metab Clin North Am 1999;28:211-22.

35. Miller JW, Crapo L. The medical treatment of Cushing's syndrome. Endocr Rev 1993;14:443-58.

36. Child DF, Burke CW, Burley DM, Rees LH, Fraser TR. Drug controlled of Cushing's syndrome. Combined aminoglutethimide and metyrapone therapy. Acta Endocrinol (Copenh) 1976;82:330-41.

37. Dewis P, Anderson DC, Bullock DE, Earnshaw R, Kelly WF. Experience with trilostane in the treatment of Cushing's syndrome. Clin Endocrinol (Oxf) 1983;18:533-40.

38. Sieber-Ruckstuhl NS, Boretti FS, Wenger M, Maser-Gluth C, Reusch CE. Cortisol, aldosterone, cortisol precursor, androgen and endogenous ACTH concentrations in dogs with pituitary-dependant hyperadrenocorticism treated with trilostane. Domest Anim Endocrinol 2006;31:63-75.

39. Ledingham IM, Watt I. Influence of sedation on mortality in critically ill multiple trauma patients. Lancet 1983:1:1270.

40. Weber MM, Lang J, Abedinpour F, Zeilberger K, Adelmann B, Engelhardt D. Different inhibitory effect of etomidate and ketoconazole on the human adrenal steroid biosynthesis. Clin Investig 1993;71:933-8.

41. Allolio B, Stuttmann R, Fischer $H$, Leonhard W, Winkelmann W. Long-term etomidate and adrenocortical suppression. Lancet 1983;2:626.

42. Allolio B, Schulte HM, Kaulen D, Reincke M, Jaursch-Hancke C. Winkelmann W. Nonhypnotic low-dose etomidate for rapid correction of hypercortisolaemia in Cushing's syndrome. Klin Wochenschr 1988:66:361-4.

43. Drake WM, Perry LA, Hinds CJ, Lowe DG, Reznek RH, Besser GM. Emergency and prolonged use of intravenous etomidate to control hypercortisolemia in a patient with Cushing's syndrome and peritonitis. J Clin Endocrinol Metab 1998;83:3542-4.

44. Krakoff J, Koch CA, Calis KA, Alexander RH, Nieman LK. Use of a parenteral propylene glycol-containing etomidate preparation for the long-term management of ectopic Cushing's syndrome. J Clin Endocrinol Metab 2001;86:4104-8. 
45. Lamberts SW, de Lange SA, Stefanko SZ. Adrenocorticotropin-secreting pituitary adenomas originate from the anterior or the intermediate lobe in Cushing's disease: differences in the regulation of hormone secretion. $J$ Clin Endocrinol Metab 1982;54:286-91.

46. Croughs RJ, Koppeschaar HP, van't Verlaat JW, McNicol AM. Bromocriptine-responsive Cushing's disease associated with anterior pituitary corticotroph hyperplasia or normal pituitary gland. J Clin Endocrinol Metab 1989;68:495-8.

47. Boscaro M, Benato M, Mantero F. Effect of bromocriptine in pituitary-dependent Cushing's syndrome. Clin Endocrinol (Oxf) 1983;19:485-91

48. Lamberts SW, Klijn JG, de Quijada M, Timmermans HA, Uitterlinden $\mathrm{P}$, de Jong $\mathrm{FH}$, et al. The mechanism of the suppressive action of bromocriptine on adrenocorticotropin secretion in patients with Cushing's disease and Nelson's syndrome. J Clin Endocrinol Metab 1980; 51:307-11.

49. Mercado-Asis LB, Yasuda K, Murayama M, Mune T, Morita H, Miura K. Beneficial effects of high daily dose bromocriptine treatment in Cushing's disease. Endocrinol Jpn 1992;39:385-95.

50. Morris D, Grossman A. The medical management of Cushing's syndrome. Ann N Y Acad Sci 2002;970:119-33.

51. T'Sjoen G, Defeyter I, Van De SJ, Rubens R, Vandeweghe M. Macroprolactinoma associated with Cushing's disease, successfully treated with cabergoline. J Endocrinol Invest 2002;25:172-5.

52. Miyoshi T, Otsuka F, Takeda M, Inagaki K, Suzuki J, Ogura T, et al. Effect of cabergoline treatment on Cushing's disease caused by aberrant adrenocorticotropin-secreting macroadenoma. J Endocrinol Invest 2004;27:1055-9.

53. Illouz F, Dubois-Ginouves S, Laboureau S, Rohmer V, Rodien P. Use of cabergoline in persisting Cushing's disease. Ann Endocrinol (Paris) 2006;67:353-6.

54. Pivonello R, Ferone D, Lamberts SW, Colao A. Cabergoline plus lanreotide for ectopic Cushing's syndrome. N Engl J Med 2005;352:2457-8.

55. Pivonello R, Ferone D, de Herder WW, Faggiano A, Bodei L, de Krijger RR, et al. Dopamine receptor expression and function in corticotroph ectopic tumors. J Clin Endocrinol Metab 2007;92:65-9.

56. Casulari LA, Naves LA, Mello PA, Pereira NA, Papadia C. Nelson's syndrome: complete remission with cabergoline but not with bromocriptine or cyproheptadine treatment. Horm Res 2004;62:300-5.

57. Shraga-Slutzky I, Shimon I, Weinshtein R. Clinical and biochemical stabilization of Nelson's syndrome with long-term low-dose cabergoline treatment. Pituitary 2006;9:151-4.

58. Heaney AP, Fernando $M$, Yong WH, Melmed S. Functional PPAR-gamma receptor is a novel therapeutic target for ACTHsecreting pituitary adenomas. Nat Med 2002;8:1281-7.

59. Hull SSA, Sheridan B, Atkinson AB. Pre-operative medical therapy with rosiglitazone in two patients with newly diagnosed pituitary-dependent Cushing's syndrome. Clin Endocrinol (Oxf) 2005;62:259-61.

60. Giraldi FP, Scaroni C, Arvat E, Martin M, Giordano R, Albiger $\mathrm{N}$, et al. Effect of protracted treatment with rosiglitazone, a PPARgamma agonist, in patients with Cushing's disease. Clin Endocrinol (Oxf) 2006;64:219-24.

61. Ambrosi B, Dall'Asta C, Cannavo S, Libe R, Vigo T, Epaminonda $P$, et al. Effects of chronic administration of PPAR-gamma ligand rosiglitazone in Cushing's disease. Eur J Endocrinol 2004;151:173-8.

62. Mullan KR, Leslie H, McCance DR, Sheridan B, Atkinson AB. The PPAR-gamma activator rosiglitazone fails to lower plasma ACTH levels in patients with Nelson's syndrome. Clin Endocrinol (Oxf) 2006;64:519-22.

63. Munir A, Song F, Ince P, Walters SJ, Ross R, Newell-Price J. Ineffectiveness of rosiglitazone therapy in Nelson's syndrome. J Clin Endocrinol Metab 2007;92:1758-63.

64. Suri D, Weiss RE. Effect of pioglitazone on adrenocorticotropic hormone and cortisol secretion in Cushing's disease. J Clin Endocrinol Metab 2005;90:1340-6.
65. Weckbecker G, Lewis I, Albert R, Schmid HA, Hoyer D, Bruns C. Opportunities in somatostatin research: biological, chemical and therapeutic aspects. Nat Rev Drug Discov 2003; 2:999-1017.

66. O'Carroll AM, Krempels K. Widespread distribution of somatostatin receptor messenger ribonucleic acids in rat pituitary. Endocrinology 1995;136:5224-7.

67. Day R, Dong W, Panetta R, Kraicer J, Greenwood MT, Patel YC. Expression of mRNA for somatostatin receptor (sstr) types 2 and 5 in individual rat pituitary cells. A double labeling in situ hybridization analysis. Endocrinology 1995; 136:5232-5.

68. Mezey E, Hunyady B, Mitra S, Hayes E, Liu Q, Schaeffer J, et al. Cell specific expression of the sst2A and sst5 somatostatin receptors in the rat anterior pituitary. Endocrinology 1998; 139:414-9.

69. Shimon I, Taylor JE, Dong JZ, Bitonte RA, Kim S, Morgan B, et al. Somatostatin receptor subtype specificity in human fetal pituitary cultures. Differential role of SSTR2 and SSTR5 for growth hormone, thyroid-stimulating hormone, and prolactin regulation. J Clin Invest 1997;99:789-98.

70. Brown MR, Rivier C, Vale W. Central nervous system regulation of adrenocorticotropin secretion: role of somatostatins. Endocrinology 1984;114:1546-9.

71. Kraicer J, Gajewski TC, Moor BC. Release of pro-opiomelanocortin-derived peptides from the pars intermedia and pars distalis of the rat pituitary: effect of corticotrophinreleasing factor and somatostatin. Neuroendocrinology 1985;41:363-73.

72. Voigt KH, Fehm HL, Lang RE, Beinert KE, Pfeiffer EF. Suppression of ACTH secretion by synthetic MSH-release inhibiting factor Pro-Leu-Gly-NH2 in Addison's disease. Horm Metab Res 1977;9:150-2.

73. Nicholson SA, Adrian TE, Gillham B, Jones MT, Bloom SR. Effect of hypothalamic neuropeptides on corticotrophin release from quarters of rat anterior pituitary gland in vitro. $\mathbf{J}$ Endocrinol 1984;100:219-26.

74. Lamberts SW. The role of somatostatin in the regulation of anterior pituitary hormone secretion and the use of its analogs in the treatment of human pituitary tumors. Endocr Rev 1988;9:417-36.

75. Invitti C, Pecori GF, Dubini A, Piolini M, Cavagnini F. Effect of sandostatin on CRF-stimulated secretion of ACTH, betalipotropin and beta-endorphin. Horm Metab Res 1991; 23:233-5.

76. Stafford PJ, Kopelman PG, Davidson K, McLoughlin L, White A, Rees LH, et al. The pituitary-adrenal response to CRF-41 is unaltered by intravenous somatostatin in normal subjects. Clin Endocrinol (Oxf) 1989;30:661-6.

77. Tyrrell JB, Lorenzi M, Gerich JE, Forsham PH. Inhibition by somatostatin of ACTH secretion in Nelson's syndrome. $\mathbf{J}$ Clin Endocrinol Metab 1975;40:1125-7.

78. Lamberts SW, Uitterlinden P, Klijn JM. The effect of the longacting somatostatin analogue SMS 201-995 on ACTH secretion in Nelson's syndrome and Cushing's disease. Acta Endocrinol (Copenh) 1989;120:760-6.

79. Julesz J, Laczi F, Janaky T, Laszlo F. Effects of somatostatin and bromocryptine on the plasma ACTH level in bilaterally adrenalectomized patients with Cushing's disease. Endokrinologie 1980;76:68-72.

80. Petrini L, Gasperi M, Pilosu R, Marcello A, Martino E. Longterm treatment of Nelson's syndrome by octreotide: a case report. J Endocrinol Invest 1994;17:135-9.

81. Ambrosi B, Bochicchio D, Fadin C, Colombo P, Faglia G. Failure of somatostatin and octreotide to acutely affect the hypothalamic-pituitary-adrenal function in patients with corticotropin hypersecretion. J Endocrinol Invest 1990;13:257-61.

82. Stalla GK, Brockmeier SJ, Renner U, Newton C, Buchfelder M, Stalla J, et al. Octreotide exerts different effects in vivo and in vitro in Cushing's disease. Eur J Endocrinol 1994; 130:125-31.

83. Schonbrunn A. Glucocorticoids down-regulate somatostatin receptors on pituitary cells in culture. Endocrinology 1982; 110:1147-54. 
84. Kraus J, Woltje M, Hollt V. Regulation of mouse somatostatin receptor type 2 gene expression by glucocorticoids. FEBS Lett 1999;459:200-4.

85. Kraus J, Woltje M, Schonwetter N, Hollt V. Alternative promoter usage and tissue specific expression of the mouse somatostatin receptor 2 gene. FEBS Lett 1998;428:165-70.

86. Bertagna $X$, Favrod-Coune $C$, Escourolle $H$, Beuzeboc $P$, Christoforov B, Girard F, et al. Suppression of ectopic adrenocorticotropin secretion by the long-acting somatostatin analog octreotide. J Clin Endocrinol Metab 1989;68:988-91.

87. Vignati F, Loli P. Additive effect of ketoconazole and octreotide in the treatment of severe adrenocorticotropindependent hypercortisolism. J Clin Endocrinol Metab 1996;81:2885-90.

88. Boerlin V, van der HJ, Beglinger C, Poon KW, Hartmann S, Dutreix C, et al. New insights on SOM230, a universal somatostatin receptor ligand. J Endocrinol Invest 2003; 26(suppl 8):14-6.

89. Lewis I, Bauer W, Albert R, Chandramouli N, Pless J, Weckbecker $G$, et al. A novel somatostatin mimic with broad somatotropin release inhibitory factor receptor binding and superior therapeutic potential. J Med Chem 2003;46:2334-44.

90. Bruns C, Lewis I, Briner U, Meno-Tetang G, Weckbecker G. SOM230: a novel somatostatin peptidomimetic with broad somatotropin release inhibiting factor (SRIF) receptor binding and a unique antisecretory profile. Eur J Endocrinol 2002; 146:707-16.

91. Hofland LJ, van der HJ, Feelders $R$, van Aken MO, van Koetsveld PM, Waaijers $M$, et al. The multi-ligand somatostatin analogue SOM230 inhibits ACTH secretion by cultured human corticotroph adenomas via somatostatin receptor type 5. Eur J Endocrinol 2005;152:645-54.

92. van der HJ, Waaijers M, van Koetsveld PM, Sprij-Mooij D, Feelders RA, Schmid HA, et al. Distinct functional properties of native somatostatin receptor subtype 5 compared with subtype 2 in the regulation of ACTH release by corticotroph tumor cells. Am J Physiol Endocrinol Metab 2005; 289:E278-87.

93. Strowski MZ, Dashkevicz MP, Parmar RM, Wilkinson $H$, Kohler M, Schaeffer JM, et al. Somatostatin receptor subtypes 2 and 5 inhibit corticotropin-releasing hormone-stimulated adrenocorticotropin secretion from AtT-20 cells. Neuroendocrinology 2002;75:339-46.

94. Boscaro M, Petersenn $S$, Atkinson $A B$, et al. Pasireotide (SOM-230), the novel multi-ligand somatostatin analogue, is a promising medcal therapy for patients with Cushing's disease: preliminary safety and efficacy results of a phase 2 study. ENDO 2006. (Abstract)

95. Krieger DT, Amorosa L, Linick F. Cyproheptadine-induced remission of Cushing's disease. N Engl J Med 1975;293:893-6.

96. Suda T, Tozawa F, Mouri T, Shibasaki T, Demura H, Shizume K. Effects of cyproheptadine, reserpine, and synthetic corticotropin-releasing factor on pituitary glands from patients with Cushing's disease. J Clin Endocrinol Metab 1983; 56:1094-9.

97. Waveren Hogervorst CO, Koppeschaar HP, Zelissen PM, Lips CJ, Garcia BM. Cortisol secretory patterns in Cushing's disease and response to cyproheptadine treatment. J Clin Endocrinol Metab 1996;81:652-5.

98. Tanakol R, Alagol F, Azizlerli H, Sandalci O, Terzioglu T, Berker F. Cyproheptadine treatment in Cushing's disease. $J$ Endocrinol Invest 1996;19:242-7.

99. Whitehead HM, Beacom R, Sheridan B, Atkinson AB. The effect of cyproheptadine and/or bromocriptine on plasma ACTH levels in patients cured of Cushing's disease by bilateral adrenalectomy. Clin Endocrinol (Oxf) 1990;32:193-201.
100.Sonino N, Boscaro M, Fallo F, Fava GA. Potential therapeutic effects of ritanserin in Cushing's disease. JAMA 1992; 267:1073.

101.Sonino N, Fava GA, Fallo F, Franceschetto A, Belluardo $P$, Boscaro M. Effect of the serotonin antagonists ritanserin and ketanserin in Cushing's disease. Pituitary 2000;3:55-9.

102. Koppeschaar HP, Croughs RJ, Thijssen JH, Schwarz F. Sodium valproate and cyproheptadine may independently induce a remission in the same patient with Cushing's disease. Acta Endocrinol (Copenh) 1983;104:160-3.

103. Colao A, Pivonello R, Tripodi FS, Orio F Jr, Ferone D, Cerbone $\mathrm{G}$, et al. Failure of long-term therapy with sodium valproate in Cushing's disease. J Endocrinol Invest 1997;20:387-92.

104.Glaser B, Kahana L, Elias V, Sheinfeld M. Sodium valproate and metyrapone for pituitary-dependent Cushing's disease. Lancet 1984;2:640.

105. Nussey SS, Price P, Jenkins JS, Altaher AR, Gillham B, Jones MT. The combined use of sodium valproate and metyrapone in the treatment of Cushing's syndrome. Clin Endocrinol (Oxf) 1988;28:373-80.

106. New hope in acne. Lancet 1979;1:1222-3.

107.Tallman MS, Nabhan C, Feusner JH, Rowe JM. Acute promyelocytic leukemia: evolving therapeutic strategies. Blood 2002;99:759-67.

108.Paez-Pereda M, Kovalovsky D, Hopfner U, Theodoropoulou M, Pagotto U, Uhl E, et al. Retinoic acid prevents experimental Cushing syndrome. J Clin Invest 2001;108:1123-31.

109. Castillo V, Giacomini D, Paez-Pereda M, Stalla J, Labeur M, Theodoropoulou $\mathrm{M}$, et al. Retinoic acid as a novel medical therapy for Cushing's disease in dogs. Endocrinology 2006; 147:4438-44.

110.Baulieu EE. The steroid hormone antagonist RU486. Mechanism at the cellular level and clinical applications. Endocrinol Metab Clin North Am 1991;20:873-91.

111. Healy DL, Chrousos GP, Schulte HM, Gold PW, Hodgen GD. Increased adrenocorticotropin, cortisol, and arginine vasopressin secretion in primates after the antiglucocorticoid steroid RU 486: dose response relationships. J Clin Endocrinol Metab 1985;60:1-4.

112.Nieman LK, Chrousos GP, Kellner C, Spitz IM, Nisula BC, Cutler GB, et al. Successful treatment of Cushing's syndrome with the glucocorticoid antagonist RU 486. J Clin Endocrinol Metab 1985;61:536-40.

113.Bertagna X, Bertagna C, Laudat MH, Husson JM, Girard F, Luton JP. Pituitary-adrenal response to the antiglucocorticoid action of RU 486 in Cushing's syndrome. J Clin Endocrinol Metab 1986;63:639-43.

114.Chu JW, Matthias DF, Belanoff J, Schatzberg A, Hoffman AR, Feldman D. Successful long-term treatment of refractory Cushing's disease with high-dose mifepristone (RU 486). J Clin Endocrinol Metab 2001;86(8):3568-73.

115.Sartor O, Cutler GB, Jr. Mifepristone: treatment of Cushing's syndrome. Clin Obstet Gynecol 1996;39(2):506-10.

Address for correspondence:

Peter Trainer

Department of Endocrinology

Christie Hospital

Wilmslow Road

Manchester. M20 4BX, UK

Fax: +44 161 4463772

Email: peter.trainer@manchester.ac.uk 